\title{
In vitro antimicrobial, anti-oxidant properties and GC-MS analysis of the crude methanolic extract and fractions of Solanum dasyphyllum Schumach and Thonn. leaves
}

Oladapo Elijah Oyinloye ( $\sim$ dapobuk2003@yahoo.com )

Olabisi Onabanjo University

Olumuyiwa. S. Alabi

University of Ibadan

Olusegun. G. Ademowo

University of Ibadan College of Medicine

\section{Research}

Keywords: S. dasyphyllum, minimum inhibitory concentration, minimum bactericidal concentration, time-kill kinetics, GC-MS

Posted Date: December 22nd, 2020

DOI: https://doi.org/10.21203/rs.3.rs-125789/v1

License: (9) (i) This work is licensed under a Creative Commons Attribution 4.0 International License. Read Full License 


\section{Abstract}

Background: Solanum dasyphyllum is a plant with several ethno-medicinal uses as food and medicine in treatment of fever, skin diseases, inflammation, stomach ache and some systemic infections. To date there is little scientific validation of the folkloric claims of $S$. dasyphyllum compared to other species of the Solanaceae family. This study determined the antimicrobial and antioxidant potential of methanol extract and fractions of the leaves of $S$. dasyphyllum and analysed the phyto-constituents using GC-MS technique.

Methods: The dried leaves of $S$. dasyphyllum were extracted by Soxhlet apparatus with $80 \%$ methanol and the crude extract subjected to Phytochemical screening and liquid-liquid fractionation. Crude extract and fractions were subjected to antimicrobial screening, minimum inhibitory concentrations (MICs) and minimum bactericidal/fungicidal concentrations (MBC/MFC) determination and time-kill kinetics study. Crude extract was assayed for antioxidant activity and analysed by GC-MS.

Results: Percentage yield of $S$. dasyphyllum was $12.5 \%$ and tested positive for flavonoids, alkaloids, saponins, cyanogenic glycosides, tannins and reducing sugars. The crude extract and fractions were active on all the isolates at concentrations $>0.5 \mathrm{mg} / \mathrm{mL}$. MICs of the crude extract and fractions ranged between 0.25 and $>4 \mathrm{mg} / \mathrm{mL}, \mathrm{MBC}$ ranged between 1 and $>4 \mathrm{mg} / \mathrm{mL}$ and MFC ranged between 0.5 and $>4 \mathrm{mg} / \mathrm{mL}$. The MBC/MIC ratio was $>4$ for dichloromethane fractions against $S$. aureus (ratio 8) and MFC/MIC ratio ethylacetate fraction against the fungi isolates (ratio 8). The time-kill kinetics study showed dichloromethane and ethylacetate fractions to be bactericidal with zero viable count at 4 - 6 hours against the isolates. The crude extract displayed moderate antioxidant with weak DPPH radical scavenging activity. The GC-MS analysis showed 29 metabolites including the phenols and polyphenols derivatives, eucalyptol, levomenthol, benzofuranone derivative, diethyl phthalate, neophytadiene, 1-Docosene, 17-Pentatriacontene, Phytol, Thunbergol and esters of decanoic acid derivatives all of which are known to have anti-infective and anti-oxidant properties.

Conclusion: This study therefore confirmed the ethno-medicinal claim of $S$. dasyphyllum and thus elucidates the potentials of the plant as a good source of bioactive compounds including those with strong anti-infective and antioxidant properties.

\section{Background}

The search for new lead compounds with antimicrobial effects is increasing due to preponderance of strains of microorganisms which exhibits resistance to existing antibiotics [1]. Antimicrobial principles have been in existence since antiquity, and it has been well preserved by nature. This is evident by the existence of microbes before mankind and man's idea that some plants had healing power against the disease caused by the microbes. Since ancient times, man has used plants to treat common infectious diseases and some of these traditional medicines still form part of the habitual treatment of various ailments [2]. Bearberry known as Arctostaphylos uva-ursi, cranberry juice known as Vaccinium macrocarpon, lemon balm known as Melissa officinalis, garlic known as Allium sativum and tee tree known as Melaleuca alternifolia, are described as broad-spectrum antimicrobial agents used in the treatment of several infections $[3,4,5]$. The essential oils of lemon balm, garlic and tee tree have useful application in the treatment of infectious diseases in the respiratory system, urinary tract, gastrointestinal and biliary systems and also on the skin [6]. Herbal remedies are known as worthy sources of novel drugs with antimicrobial activity. Cinchona bark identified over 300 years ago, resulted in the discovery of notable anti-malarial compound named quinine, and then also, the discovery of artemisinin from sweet wormwood plant, Artemisia annua, and the development of its derivatives [7, 8]. The thrust in ethnopharmacology is to identify plants traditionally used in the treatment of diseases and derive bioactive compounds which can be developed into novel drugs. Nonetheless, ethnomedicine is the main practice that is used in primary healthcare in rural areas where modern healthcare facilities are lacking [9].

The increasing prevalence of multidrug resistant (MDR) strains of microorganisms and the appearance of strains with reduced susceptibility to antibiotics originally effective against them raised the specter of untreatable bacterial infections and add urgency to the search for new infection-fighting strategies [10].

Hypersensitivity and immune-suppression are some adverse effects associated with most chemotherapeutic agents against antimicrobial drugs. The search for novel chemotherapeutic substances devoid of this adverse effect should therefore be continued, exploring all possible strategies. Natural products, particularly medicinal plants still remain the major and innovative sources for therapeutic agents.

Currently, researches on lead compounds from natural products primarily focuses mainly on plants since they are more readily available and can be selected on the basis of their ethno-medicinal uses. Solanum dasyphyllum is a semi-woody under shrub to $1 \frac{112}{2} \mathrm{~m}$ high, hirsute or armed with prickles, naturalized, not known in the wild state, and occurring throughout the region and tropical Africa to South Africa [11]. It is very closely related to $S$. macrocarpon Linn. Solanum is a plant of the Solanaceae family, with about 2000 species, is one of the largest genera of flowering plants, and has a centre of diversity in the New World tropics. The leaves and fruits of $S$. dasyphyllum are being used as food, while leaf-saps are used as medicine in treatment of stomach ache and other infections [12]. S. dasyphyllum is known to be rich in some phenolic metabolites which are known antimicrobial and antiinflammatory phytochemicals present in many plants for a variety of disease causing agents including malaria plasmodium, bacteria and fungi infections and inflammatory disorders. To date there is little scientific validation of the folkloric claims of $S$. dasyphyllum plant. However, there are documented evidences corroborating pharmacological activities of other species of the Solanaceae family in infectious diseases treatment [13, 14]. There is therefore, need to validate scientifically the folkloric claims of $S$. dasyphyllum used in traditional medicine. The present study was designed to determine the antimicrobial and antioxidant potentials of the crude methanolic extract and four fractions (n-hexane, dichloromethane, ethylacetate and aqueous) of the leaves of S. dasyphyllum and also carry out GC-MS analysis of the crude methanolic extract to evaluate the various bioactive compounds present.

\section{Materials And Methods}




\section{Collection of plant samples}

The leaves of Solanum dasyphyllum were collected from Akunba, Akoko in Ondo State, Nigeria in April, 2017. The plant was authenticated at the Federal Research Institute of Nigeria (FRIN), Ibadan, Oyo-State where it was assigned a voucher number: F.H.I109799 and deposited at the herbarium unit of the Department of Pharmacognosy, Faculty of Pharmacy, and University of Ibadan for future referencing.

\section{Extraction of plant samples}

The leaves of $S$. dasyphyllum were air-dried away from direct sunlight after which it was grounded into coarse powder with a mechanical grinder. Two hundred gram $(200 \mathrm{~g})$ of the dried powdered leave sample was extracted with a mixture of $80 \%$ methanol and $20 \%$ water in a Soxhlet extractor apparatus for 72 hours. The plant extract was filtered with Whatman grade 1 paper and concentrated on rotary evaporator at reduced pressure. The concentrate was then lyophilized (freeze dried), the yield determined and the crude extract stored in a vial at $-20^{\circ} \mathrm{C}$ for further studies.

\section{Phytochemical analysis of crude extract}

Qualitative and quantitative phytochemical screening of the methanolic extract was done as previously described [15]. The presence of selected phytochemical constituets such as flavonoids, alkaloids, saponins, cyanogenic glycosides, tannins and reducing sugars were investigated.

\section{Fractionation of the crude extract}

The lyophilized crude extracted of Solanum dasyphyllum leave was reconstituted with $80 \% \mathrm{v} / \mathrm{v}$ methanol, poured into the fractionating funnel and partitioned separately with $n$-hexane first, dichloromethane and then ethylacetate solvent by liquid-liquid fractionation technique. The different fractions of the $n$-hexane, dichloromethane, ethylacetate and the aqueous were then concentrated on rotary evaporator under reduced pressure and then lyophilized as previously mentioned. The lyophilized powdered fractions were stored at $-20^{\circ} \mathrm{C}$ for further analysis.

\section{Collection and authentication of test clinical isolates}

Four clinical multidrug resistant bacteria isolates (Staphylococcus aureus, Bacillus subtilis, Escherichia coli and Pseudomonas aeruginosa) and four clotrimazole resistant clinical fungi (Aspergillus niger, Rhizopus spp., Candida albicans and Penicillium spp.) were collected from the achieve of the Laboratory in the Department of Pharmaceutical Microbiology, Faculty of Pharmacy, University of Ibadan. The isolates were confirmed for purity and identity using standard microbiological techniques, inoculated on sterile agar slants and stored at $4^{\circ} \mathrm{C}$ for further study.

\section{Antimicrobial screening of the crude extract and fractions}

The crude methanolic extract and the different fractions (n-hexane, dichloromethane, ethylacetate and aqueous) of Solanum dasyphyllum leaves were screened for antimicrobial activities against selected test isolates using agar-well-diffusion method as described previously with some modifications [16]. Briefly, $20 \mathrm{mg}$ of the extract and each of the fractions were weighed separately and dissolved in $10 \mathrm{~mL}$ of methanol in a tube each to give the stock concentration of $2 \mathrm{mg} / \mathrm{mL}$. The concentration was serially diluted twice by taken $5 \mathrm{~mL}$ of the stock concentrate into $5 \mathrm{~mL}$ of fresh methanol to give the second and third concentrations of $1 \mathrm{mg} / \mathrm{mL}$ and $0.5 \mathrm{mg} / \mathrm{mL}$. Culture plates of the test microorganisms were prepared according to the manufacturer's instructions and test microorganisms prepared into suspension for inoculation on the agar plates. Microbial suspensions were prepared by taking speck of colonies of each bacteria (overnight culture on nutrient agar at $37^{\circ} \mathrm{C}$ ) and fungi (cultured on Sabouraud dextrose agar for $48-72$ hours) using a sterile wire loop, separately dispersed in normal saline and agitated with vortex mixer to form an homogenised suspensions. The suspensions were further diluted to $0.5 \mathrm{MacF}$ arland standards with sterile normal saline. With the aid of a sterile swab each of the diluted suspensions were inoculated on the dried surfaces of separate Mueller Hinton agar plates for bacteria and Sabouraud dextrose agar plates for fungi by surface spreading. Wells of approximately 6 $\mathrm{mm}$ in diameter and $2.5 \mathrm{~mm}$ deep were made on the surface of the inoculated media using a sterile $6 \mathrm{~mm}$ cup-borer. The number of wells corresponded with the number of the diluted extracts (15) and the controls (2). Each well after labeling was filled with two to three drops of the corresponding diluted extract/fractions. The controls include methanol $(80 \% \mathrm{v} / \mathrm{v})$ as negative and gentamicin $(10 \mu \mathrm{g} / \mathrm{mL})$ and ketoconazole $(10 \mu \mathrm{g} / \mathrm{mL})$ as positive controls for bacteria and fungi respectively. The plates were first maintained on the bench at room temperature for 2 hours to enable the diffusion of the extracts into the medium after which the bacteria inoculated agar plates were incubated at $37^{\circ} \mathrm{C}$ for 24 hours, and those for fungi at $25^{\circ} \mathrm{C}$ for 48 to 72 hours.

All the inoculation procedures were undertaken under aseptic conditions and in duplicates. The zones of inhibition around the wells were measured as diameters in millimeters $(\mathrm{mm})$ with the aid of a transparent ruler for all the two replicates and average measurements recorded.

\section{Determination of Minimum Inhibitory Concentrations (MICs) of the crude extract and fractions}

The minimum inhibitory concentration (MIC) of the methanolic extract of Solanum dasyphyllum leaves and the fractions (n-hexane, dichloromethane, ethylacetate and aqueous) were determined using the agar-dilution method as described by Akinpelu and Kolawole [17]. From the powdered crude extract and fractions, $800 \mathrm{mg}$ was weighed and dissolved in $10 \mathrm{~mL}$ of methanol to give a concentration of $80 \mathrm{mg} / \mathrm{mL}$. This was serially diluted to give five lower concentrations: $40 \mathrm{mg} / \mathrm{mL}, 20 \mathrm{mg} / \mathrm{mL}, 10 \mathrm{mg} / \mathrm{mL}, 5 \mathrm{mg} / \mathrm{mL}$ and $2.5 \mathrm{mg} / \mathrm{mL}$. The agar-extract media were prepared by adding $1 \mathrm{~mL}$ of each of the stock concentrate and the five serially diluted concentrations into $19 \mathrm{~mL}$ of pre-sterilized molten Mueller Hinton agar (for bacteria) and Sabouraud dextrose agar (for fungi) to give the final concentrations of $4 \mathrm{mg} / \mathrm{mL}, 2 \mathrm{mg} / \mathrm{mL}, 1 \mathrm{mg} / \mathrm{mL}, 0.5 \mathrm{mg} / \mathrm{mL}, 0.25 \mathrm{mg} / \mathrm{mL}$ and $0.125 \mathrm{mg} / \mathrm{mL}$ of the agar-extract media. The agarextract media were poured into well labeled Petri dishes and permitted to solidify under laminar flow. Bacteria and fungi cultures and suspensions were prepared from their overnight cultures as described earlier above. With the aid of a sterile swab each of the diluted suspensions were inoculated on the 
respective sectors on the surface of the agar plates by surface spreading. After streaking of the test isolates to the respective labeled sectors of the agar plates, the plates were incubated at $37^{\circ} \mathrm{C}$ for 24 hour for bacteria and at $25^{\circ} \mathrm{C}$ for $48-72$ hours for fungi. The experiment was carried out in duplicates for each test microorganism. Presence or absence of growth was examined on each plate, and MIC was taken as the lowest concentration that prevented the growth of the test microorganisms.

\section{Assessment of Minimum Bactericidal Concentration (MBC) of the crude extract and fractions}

The minimum bactericidal concentration (MBC) for the methanolic extract and the fractions (n-hexane, dichloromethane, ethylacetate and aqueous) was determined using the method described by Akinpelu et al., [18]. Briefly, sterile cotton swabs was used to swab the surface of sectors of the MIC agar plate showing no visible growth (i.e. concentrations $\geq \mathrm{MBC}$ of the extract and each fraction against each isolates) and the cotton swab immediately swab onto the surface of another fresh, well labeled Mueller Hinton agar plates. The plates were then incubated at $37^{\circ} \mathrm{C}$ for up to 72 hours for both bacteria and fungi. The MBC for the individual isolate is the minimum concentration of the extract/fraction during the MIC assay that did not show any microbial growth on the fresh Mueller Hinton agar plates. This procedure was done in duplicate and the average MBC value recorded.

\section{Determination of the bacterial time-kill kinetics of the extract and fractions}

The modified method described by Akinpelu et al. [18], was used to determine the time-kill kinetics of the extract and fractions against selected isolates ( $S$. aureus, E. coli and $C$. albicans). The isolates were initially standardized by dispersing speck of colonies of each bacterium (overnight culture on nutrient agar at $37^{\circ} \mathrm{C}$ ) and fungi (cultured on Sabouraud dextrose agar for $48-72$ hours) in normal saline with a sterile wire loop and vortexed to form an homogenised suspension. The suspension was further diluted to 0.5 MacFarland standards (approximately $10^{6} \mathrm{cfu} / \mathrm{mL}$ ) with sterile normal saline. Exactly $0.5 \mathrm{~mL}$ of the standardized suspension of the culture was added to $9.5 \mathrm{~mL}$ of Mueller Hinton broth containing the different concentrations of the extracts relative to their different MBCs (Crude methanol extract $8 \mathrm{mg} / \mathrm{mL}$, ethylacetate fraction $8 \mathrm{mg} / \mathrm{mL}$, $\mathrm{n}$-hexane fraction $4 \mathrm{mg} / \mathrm{mL}$, dichloromethane fractions $4 \mathrm{mg} / \mathrm{mL}$ and aqueous fraction $4 \mathrm{mg} / \mathrm{mL}$ ). The microbe-extract-reaction media were held at room temperature and at an interval of time corresponding to 0 , $1,2,3,4,5$ and 6 hours, $0.1 \mathrm{~mL}$ of each microbe-extract reaction media were withdrawn and immediately transferred to $9.9 \mathrm{~mL}$ peptone water recovery medium ( $10^{-2}$ dilution). This was then serially diluted twice with fresh sterile peptone water and the last two dilutions $\left(10^{-4}\right.$ and $\left.10^{-6}\right)$ plated for viable counts. The bacteria culture plates were incubated at $37^{\circ} \mathrm{C}$ for 24 hours, while fungi cultured plate was incubated at $25^{\circ} \mathrm{C}$ for up to 72 hours. Control culture plates containing each of the test isolate without the addition of extract or fractions were also done to determine isolates' growth rate. After the respective period of incubation, the emergent bacteria and fungi colonies were counted and express in cfu/mL. Graph of percentage survivor against time was plotted for the extract and fractions against each of the three isolates to determine the pattern of the kill kinetics.

\section{Determination of antioxidant potential of the crude methanolic extract}

The antioxidant potential of the crude methanolic extract of $S$. dasyphyllum leaves was evaluated by determining the total phenolic cotent (TPC), ferric ion reducing antioxidant power assay (FRAP), total antioxidant content (TAC) and 1,1-diphenyl-2-picryl hydrazyl (DPPH) free radical-scavenging activity.

\section{Total phenolic content (TPC)}

The crude methanolic extract's total phenol contents were determined by the Folin-Ciocalteu assay as previously described by Ebrahimzadeh et al. [19]. The crude extract sample was diluted to different concentrations, $200,400,600,800$ and $1000 \mu \mathrm{g} / \mathrm{mL}$, and 0.5 ml of different dilutions were separately mixed, each with $5 \mathrm{~mL}$ of Folin-Ciocalteu reagent (to give a ratio of 1:10 dilution) and left for $5 \mathrm{~min}$ before $4 \mathrm{~mL} 1 \mathrm{M}$ aqueous sodium carbonate was then added. The mixture was allowed to stand for another $15 \mathrm{~min}$ and the phenols were determined by colorimetric method at $765 \mathrm{~nm}$. The concentrations of phenolic compounds in $S$. dasyphyllum crude methanolic extract were expressed as gallic acid equivalents (GAEs). All assays were conducted in triplicate and the mean values were recorded.

\section{Ferric ion reducing antioxidant power assay (FRAP)}

The ferric ions reducing power of the crude methanolic extract was measured by a method previously described by Phatak and Hendre [20]. The crude extract was diluted to different concentrations $(200,400,600,800$ and $1000 \mu \mathrm{g} / \mathrm{mL})$ and were mixed, each with $2.5 \mathrm{ml}$ of $20 \mathrm{mM}$ phosphate buffer and 2.5 $\mathrm{mL} 1 \%, \mathrm{w} / \mathrm{v}$ potassium ferric cyanide. The mixture was then incubated at $50{ }^{\circ} \mathrm{C}$ for 30 min and afterwards, $2.5 \mathrm{~mL}$ of $10 \%$, w/v trichloroacetic acid and 0.5 $\mathrm{mL}$ of $0.1 \%, \mathrm{w} / \mathrm{v}$ ferric chloride were added to the mixture, and kept aside for $10 \mathrm{~min}$. Ascorbic acid was used as positive reference standard and the absorbance was measured at $700 \mathrm{~nm}$. All assays were run in triplicate and the mean values recorded.

\section{Total antioxidant content (TAC)}

The total antioxidant content of the crude extract was evaluated by phosphor-molybdenum assay as previously described by Phatak and Hendre [20]. The molybdate reagent solution was prepared by adding $1 \mathrm{~mL}$ each of $0.6 \mathrm{M}$ sulfuric acid, $28 \mathrm{mM}$ sodium phosphate and $4 \mathrm{mM}$ ammonium molybdate into 20 $\mathrm{mL}$ of distilled water and made up to $50 \mathrm{~mL}$ with distilled water. The crude extract was serially diluted to five different concentrations (200, $400,600,800$ and $1000 \mu \mathrm{g} / \mathrm{mL}$ ) and equal volume added to each of the five test tubes individually containing $3 \mathrm{~mL}$ of distilled water and $1 \mathrm{~mL}$ of molybdate reagent solution. These tubes were incubated at $95^{\circ} \mathrm{C}$ for $90 \mathrm{~min}$ after which the tubes were normalized to room temperature for $20-30 \mathrm{~min}$ and the absorbance of the reaction mixture measured at $695 \mathrm{~nm}$. Ascorbic acid was used as positive reference standard at the same concentrations and absorbance as the crude extract. The protocol was done in triplicate and the mean values recorded.

\section{DPPH free radical-scavenging activity evaluation}


The free radical-scavenging activity of the crude methanolic extract of $S$. dasyphyllum was determined using 1,1-diphenyl-2-picryl hydrazyl radical as previously described by Ebrahimzadeh et al. [19]. The crude extract was diluted to different concentrations $(200,400,600,800 \mathrm{and} 1000 \mathrm{\mu g} / \mathrm{mL}) \mathrm{and}$ equal volumes were added to the methanolic solution of DPPH $(100 \mu \mathrm{M})$. This was left at room temperature for 15 min after which the absorbance was measured at $517 \mathrm{~nm}$. The protocol was carried out in triplicate and the mean value recorded. Ascorbic acid (Vitamin C) was used as standard controls at the same concentrations and measured at the same wavelength with the crude extract.

\section{Screening for bioactive compounds by Gas Chromatography-Mass Spectrometry (GC-MS)}

The crude methanolic extract of S. dasyphyllum was analysed by Gas Chromatograph (Hewlett-Package 5890) coupled to VG Analytical Mass Spectrometer (70-250S) with a fused silica capillary column (CP-Sil 5CB: $30 \mathrm{~m} \times 0.25 \mathrm{~mm}$ ID $\times 1 \mu \mathrm{m}$ of capillary column). Helium gas was used as carrier at flow rate of $1 \mathrm{~mL} / \mathrm{min}$. The oven was set at a temperature of $90^{\circ} \mathrm{C}$ initially and sustained for $2 \mathrm{~min}$ before heating at $10^{\circ} \mathrm{C} / \mathrm{min}$ to $270^{\circ} \mathrm{C}$ and held isothermally for $15 \mathrm{~min}$. A scan was applied to cover a mass range from 36 to 600 amu for $0.6 \mathrm{~s}$ at $70 \mathrm{eV}$ ionization voltage. Important constituents of the analysed crude extract were identified by matching their MS and retention index data with those of the standards using computer search on a NIST version 2.1 MS Library.

\section{Results}

\section{Percentage yield and Phytochemical Screening}

The percentage yield of the methanolic extract was $12.5 \%$. The result of the preliminary qualitative and quantitative screening of the crude methanolic extract of $S$. dasyphyllum is presented in table 1. The phyto-constituents present included: flavonoids (0.0063), alkaloids (1.284), saponins (0.395), cyanogenic glycosides (0.016), tannins (0.037) and reducing-sugars (0.863).

\section{Determination of the antimicrobial activity of the crude extract and fractions}

The results of the antibacterial screening of the crude extract and the fractions against the clinical isolates are presented in table 2 and 3 . All the bacterial isolates used in this study were susceptible to the dichloromethane and ethylacetate fractions at concentrations of $\geq 0.5 \mathrm{mg} / \mathrm{mL}$. However, the crude methanolic extract and the $\mathrm{n}$-hexane fraction are not active against $E$ coli isolate at $0.5 \mathrm{mg} / \mathrm{mL}$ but active at $\geq 1 \mathrm{mg} / \mathrm{mL}$ concentration (Table 2 ). Both the crude extract and the three fractions were more active on the Gram-positive than Gram-negative bacteria with the crude extract (MESd) and dichloromethane fraction (SdDMF) showing highest activity against the $B$. subtilis and $S$. aureus isolates (Gram positives) with zones of inhibition between $20 \pm 0.5$ and $21 \pm 0.3 \mathrm{~mm}$. The aqueous fraction (SdAQF) showed relatively highest activity against the Gram negatives, Escherichia coli and $P$ s. aeruginosa, with zones of inhibition of $18 \pm 0.3 \mathrm{~mm}$ and $18 \pm 2.5 \mathrm{~mm}$ respectively while ethylacetate fraction (SdEAF) showed higher activity against $P$ s. aeruginosa with zone of inhibition of $20 \pm 1.3 \mathrm{~mm}$ compared to the $E$ coli. For both the crude extract and fractions, the activities against the bacterial isolates were seen to slightly increase with increase in concentrations (Table 2).

The results of the antifugal activities of the crude extract and the fractions against the clinical isolates are presented in table 3 . Highest activity was recorded against Aspergillus niger by ethylacetate fraction (SdEAF) with zone of inhibition of $22 \pm 3.5 \mathrm{~mm}$ followed by dichloromethane fraction (SdDMF) with zone of inhibition of $21 \pm 0.6 \mathrm{~mm}$ at $2 \mathrm{mg} / \mathrm{mL}$ concentration. The $\mathrm{n}$-hexane fraction (SdHXF) was the most active against the Candida albican and Penicillium sp. with zones of inhibition of $16 \pm 0.1 \mathrm{~mm}$ and $20 \pm 0.5 \mathrm{~mm}$ respectively at $2 \mathrm{mg} / \mathrm{mL}$ concentration. The crude methanolic extract (MESd) was found to be more active against Penicillium specie and Aspergillus niger compared to the other fungi. While the crude methanolic extract (MESd) was not active against $C$. albican at concentrations below $2 \mathrm{mg} / \mathrm{mL}$, the aqueous fraction (SdAQF) did not show any activity at $\leq 2 \mathrm{mg} / \mathrm{mL}$ against Aspergillus niger and Rhizopus sp. Activities of the crude methanolic extract and most of the fractions were seen to slightly increase with increase in concentrations against the fungi (Table 3).

\section{Minimum inhibitory and cidal concentrations determination}

The results of the MICs and MBCs/MFCs of the extract and fractions against the bacteria and fungi isolates are presented in table 4. The MICs of the crude extract (MESd) and its fractions against the bacterial and the fungal isolates ranged between 0.25 and $>4 \mathrm{mg} / \mathrm{mL}$. The dichloromethane fraction was found to have the lowest MIC value $(0.5 \mathrm{mg} / \mathrm{mL})$ against the $S$ aureus compared to the crude and other fractions while the crude had the lowest ( 0.25 $\mathrm{mg} / \mathrm{mL}$ ) against the $B$ subtilis. For the fungi isolates, the lowest MIC value of $0.25 \mathrm{mg} / \mathrm{mL}$ was recorded for dichloromethane fraction against Rhizopus sp, A. niger and Penicillium sp. The same $0.25 \mathrm{mg} / \mathrm{mL} \mathrm{MIC}$ value was also recorded for the ethylacetate fraction against Rhizopus sp. The MBC of the crude extract and the fractions ranged between 1 and $>4 \mathrm{mg} / \mathrm{mL}$ while the MFC ranged between 0.5 and $>4 \mathrm{mg} / \mathrm{mL}$. The MBC/MIC ratio was $>4$ for dichloromethane fractions (SdDMF) against $S$. aureus (ratio 8) and MFC/MIC ratio $>4$ for ethylacetate fraction (SdEAF) against all the fungi isolates (ration 8) as presented in table 4.

\section{Time-Kill kinetics determination}

The results of the time-kill kinetics of bactericidal activities of the crude methanolic extract of $S$. dasyphyllum (MESd) and its fractions against $S$. aureus, $E$. coli and $C$. albicans showed that the percentage viable count decrease with time at varying degree. The reduction was close to zero count at 4 hour for eathylacetate (SdEAF) and 5hour for dichloromethane (SdDMF) fraction against the $S$ aureus and E coli isolates (Figure 1 and 2). However, the results of the time-kill kinetics against the $C$. albicans showed that the viable count reduced to zero with dichloromethane fraction (sdDMF) at 5 hour and ethylacetate fraction at 6hour (Figure 3). 
The results of the antioxidant assay of the crude methanolic extract are presented in table 5 . The absorbance recorded by the crude methanolic extract for (TPC, FRAP and TAC) increases with increase in concentration which also compares relatively well but weaker than the respective standards. The DPPH assay showed decrease in absorbance with increase in concentration of the crude extract and the standard. However, the crude extract demonstrated weaker DPPH radical scavenging activity compared to the ascorbic acid standard for each of the concentration.

\section{GC-MS analysis of the crude extract}

The total ion current chromatogram of the crude methanolic extract of the $S$. dasyphyllum is presented in figure 4. The GC-MS analysis showed that the crude extract contained 29 metabolites including benzene, eucalyptol, levomenthol, benzofuranone derivative, diethyl phthalate, neophytadiene, 1Docosene, 17-Pentatriacontene, Phytol, Thunbergol, esters of decanoic acid derivatives such as 6.10.14-trimethyl-2-pentadecanone, 9,12-Octadecadienoic acid, Methyl 11-methyl-dodecanoate, n-Hexadecanoic acid, (Table 6).

\section{Discussion}

The emergence of resistant microorganisms against currently available antibiotics including those for last resort, both at the clinical and community level, has necessitated the need for continuous search for alternative agents to combat this ugly menace. In this study, the preliminary qualitative and qualitative phytochemical screening of the crude methanolic extract of the leave of Solanum dasyphyllum revealed the presence of flavonoids, alkaloids, saponins, cyanogenic glycosides, tannins and the reducing sugars (Table 1). This correlated with previous reports of some other authors who worked on $S$ dasyphyllum [12] and other species of the Solanaceae family such as S. incanum L., S. microcarpon L. and S. melongena L. [21, 22, 23]. The crude methanolic extract and fractions of the leaves of $S$. dasyphyllum exhibited antimicrobial activity against both the clinical bacteria and fungi isolates as revealed by the susceptibility test results in this study (Table 2 and 3 ). Within the bacteria genera, the activities of the crude extract and the different fractions varied but were found to be active against all the bacteria genera in this study ( $S$. aureus, E coli, $P$. aeruginosa and $B$. subtilis). This phenomenon is referred to as broad-spectrum antibacterial action. This broad-spectrum antibacterial activity has been previously reported among some other species of the Solanaceae family by some authors. Akanmu et al. [22] reported activities of the aqueous and methanol leaf extracts of $S$. incanum against $S$. aureus, $P$. aeruginosa, $S$. pyogenes and $K$. pneumoniae. Indhumathi and Mohandass [13] also reported similar broad-spectrum antibacterial activity of the ethanolic extract of $S$. incanum against $S$. aureus, B. subtilis, P. aeruginosa, Salmonella paratyphi and Vibro cholerae. Amutha [24] worked on the antibacterial activity of extract of $S$. melongena seed against human bacterial pathogens. According to Amutha's report, activity was observed against $S$ aureus and $E$ coli. Manal et al. [21] reported the antimicrobial activity of the methanolic extract of $S$. incanum ripe fruit against bacterial ( $B$ subtilis and $E$ coli) and fungal ( $C$. albicans and $A$. niger) isolates. In this study, the different genera of the fungi isolates were susceptible at varying degrees to the crude extract and the different fractions and thus also maintained the broad spectrum action against the fungi isolates. Prakash and Jain [25] similarly studied the antifungal activity of the crude extract of $S$. nigrum and reported activity against $A$. niger, A. flavus and $C$. albicans.

The broad-spectrum of activities exhibited by the crude methanolic extract and the different fractions in this and previous studies suggests that the extracts and fractions contain multiple antimicrobial constituents or single constituent with broad-spectrum property. Previous reports have demonstrated that some secondary metabolites present in plant extracts possess antimicrobial properties [26, 27]. Phytoconstituents such as saponins, alkaloids, tannins, flavonoids, glycosides, etc, have been tested and confirmed for antimicrobial property [28, 27, 29]. The presence of these phytoconstituents in this study further suggests that these metabolites might have contributed to the broad-spectrum antimicrobial activity observed.

In this study, the minimum inhibitory concentration (MIC) of the crude methanolic extract and fractions against both the bacteria and fungi isolates falls within the range 0.25 and $>4 \mathrm{mg} / \mathrm{mL}$ while the minimum bactericidal and minimum fungicidal concentrations (MBC/MFC) falls within the range 0.5 and $>4$ $\mathrm{mg} / \mathrm{mL}$. Akanmu et al. [22] in their study on the methanolic and aqueous extract of $S$ incanum had slightly higher MIC values between 5 and $7.5 \mathrm{mg} / \mathrm{mL}$ and much higher MBC values between 20 and $>80 \mathrm{mg} / \mathrm{mL}$ against the bacteria isolates with the methanolic extract showing the greatest activity. To consider an antimicrobial agent as either static or cidal, the ratio of the MBC or MFC to MIC is usually calculated. For the agent to be considered cidal in action the ratio of the MBC or MFC to MIC must be less than or equal to 4 [30]. In this study, the activity of the crude methanolic extract is considered bactericidal against $B$. subtilis and $P$ aeruginosa, and fungicidal against Rhizopus sp and $C$. albicans. The aqueous and $\mathrm{n}$-hexane fractions both exhibited cidal effect against all the bacterial isolates while dichloromethane fraction exhibited cidal action against all the fungi isolates used in this study. This was evident from the results of the time-kill kinetic study and thus reflects the strong antimicrobial properties of the Solanaceae family and their potential as possible source of novel therapeutic agents. The kill kinetics study carried out in this study revealed the strong bactericidal and fungicidal actions of the crude extract and the fractions against some isolates. As observed in figures 1 and 2 in this study, ethylacetate (SdEAF) at $8 \mathrm{mg} / \mathrm{mL}$ and dichloromethane (SdDMF) fractions at $4 \mathrm{mg} / \mathrm{mL}$ killed all the bacterial isolates after 4hours and 5hours of actions respectively against the two bacteria (Staphylococcus aureus and Escherichia coli), while in the case of the fungi, fungicidal action of the dichloromethane (SdDMF) and ethylacetate (SdEAF) fractions was observed after 5 and 6 hours respectively, against the $C$. albicans. To the best of our knowledge, this is the first time that the time-kill kinetics study on $S$ dasyphyllum will be reported. However, in a similar study carried out by Oladosu et al. [31] but with a different plant (Acacia nilotica), complete killing of $S$. aureus and $P$ aeruginosa isolates was recorded after 8hours with the methanolic extract at $1 \mathrm{mg} / \mathrm{mL}$ and $2 \mathrm{hours}$ at $2 \mathrm{mg} / \mathrm{mL}$ concentration of the extract. This thus corroborates the microbicidal potentials of extracts from medicinal plants such as $S$. dasyphyllum extract and fractions in this study.

The antioxidant assay of the crude methanolic extract of $S$. dasyphyllum carried out in this study revealed a moderate antioxidant activity with weak DPPH radical scavenging activity. This may be linked with the low level of flavonoids in the crude extract as plant rich in flavonoids and polyphenols are known 
to possess strong antioxidant property and DPPH radical scavenging activity [32, 19]. Similar report was documented by Sodeinde et al [12] in their study on the antioxidant activity of $S$. dasyphyllum leaves and fruit extracts.

The GC-MS analysis of the crude methanolic extract revealed the presence of some notable metabolites such as phytol, an acyclic diterpene usually used as precursor for production of vitamin E and K1, 1-methyl-3-(1-methylethyl)-benzene (p-Cymene), a monoterpene with an antioxidant, anti-inflammatory, antinociceptive, anxiolytic, anticancer and antimicrobial properties [33]. Eucalyptol is a cyclic ether and monoterpenoid with anti-inflammatory, antioxidant and analgesic effects in various diseases, including respiratory disease, pancreatitis, colon damage, cardiovascular and neurodegenerative diseases [34]. Levomenthol has antipruritic, anti-inflammatory, antibacterial and antifungal properties and it's useful in the treatment of upper respiratory diseases and superficial skin infections associated with inching [35]. Dihydroactinidiolide (5,6,7,7a-tetrahydro-4,4,7a-trimethyl-, (R)-2(4H)-Benzofuranone) is a volatile terpene. Paradrine (4-hydroxyamphetamine) is a sympathetic nervous system stimulant useful in a medical process called mydriasis.

Hexahydrofarnesylacetone (2-Pentadecanone, 6,10,14-trimethyl) is a member of the class of compounds known as sesquiterpenoids. Caryophyllene oxide is one of the major sesquiterpenes suitable for medicinal uses such as an anti-inflammatory, local anesthetics, antioxidant, and perhaps in cancer treatment [36]. To our knowledge, this is the first time that the GC-MS analysis of $S$. dasyphyllum crude extract will be described. Previous studies have focused on other species of the Solanaceae family such as S. nigrum, S. incanum etc. Jasim et al. [37] carried out GC-MS analysis to characterize the alkaloid constituents and antimicrobial activity of S. nigrum. Sundar and Pillai [14] also carried out GC-MS profiling of petroleum ether, methanol and ethanol extract of $S$. incanum leaves. In another comprehensive study carried out by El-Shaboury et al. [38], the diversity of eleven species of Solanum (S. villosum Mill, S. villosum L, S. nigrum, S. incanum L, S. coagulans, S. schimperianum, S. macracanthum, S. glabratum, S. torvum, S. sisymbriifolium and S. dulcamara) from southwest Saudi Arabia was assessed. The assessment was based on the differences in the secondary metabolites of the ethanol extracts of the different species using GC-MS analysis. Their findings revealed 87 different phyto-constituents at six different retention times. Most of the metabolites identified by the GC-MS analysis in the different species were also described in this study.

\section{Conclusion}

From the findings in this study, it is very clear that $S$. dasyphyllum, like most other medicinal plants, is a good source of active metabolites that may be of clinical value. The various bioactive compounds revealed by the phyto-compound screening and GC-MS analysis suggest that $S$. dasyphyllum is a reservoir of various bioactive metabolites with excellent anti-infective and anti-oxidant potential that may be useful in the development of better and effective natural and semi-synthetic drug products.

\section{Abbreviations}

GC-MS: Gas Chromatography-Mass Spectrometry, MDR: Multidrug resistant, MIC: Minimum Inhibitory Concentration, MBC: Minimum Bactericidal Concentration, MFC: Minimum Fungicidal Concentration, TAC: Total Antioxidant Capacity, TPC: Total Phenol Content, FRAP: Ferric ion reducing antioxidant power, DPPH: 1,1-diphenyl-2-picryl hydrazyl assay

\section{Declarations}

\section{Acknowledgement}

The authors acknowledged the staff in the laboratory of the Department of Pharmaceutical Microbiology, Faculty of Pharmacy, University of Ibadan, Ibadan for providing bench space, archived microbial strains and equipment for some aspect of this research.

\section{Authors' contributions}

OE conceptualized the research idea, study design, data collection, analysis and interpretation, and manuscript write-up. OS worked on the data analysis, interpretation, supervision and manuscript write up. OG worked on data analysis, interpretation, supervision, and manuscript write-up. All authors read and approved the final copy of the original manuscript.

\section{Funding}

No grant was secured to support this research.

\section{Competing interests}

Authors have declared that no competing interests exist.

\section{Availability of data and materials}

The datasets and other materials used in this study are available and included in this article.

\section{Ethics approval and consent to participate}

Not applicable

\section{Consent for publication}


Not applicable

\section{Author details}

${ }^{1}$ Department of Pharmacology, Faculty of Basic Medical Sciences, Obafemi Awolowo College of Health Sciences Olabisi Onabanjo University, Sagamu Campus, Nigeria.

${ }^{2}$ Department of Pharmaceutical Microbiology, Faculty of Pharmacy University of Ibadan, Ibadan, Nigeria.

${ }^{3}$ Pharmacology and IAMRAT Department, College of Medicine, University of Ibadan, Ibadan, Nigeria

\section{References}

1. Rios JL, Recio MC. Medicinal plants and antimicrobial activity. Journal of Ethnopharmacology. 2005; 100(1-2): 80-84.

2. Jamshidi-Kia F, Lorigooini Z, Amini-Khoei H. Medicinal plants: Past history and future perspective. Journal of Herbmed Pharmacology. 2018 ; 7(1): 1-7.

3. Heinrich M, Barnes J, Gibbons S, Williamson EM. Fundamentals of Pharmacognosy and Phytotherapy. Churchill Livingstone, Elsevier Science Ltd., UK; 2004.

4. Amalaradjou MAR, Venkitanarayanan K. Natural approaches for controlling urinary tract infections. In: Urinary tract infections. Tenke P (ed), In Tech, 2011. p 227-228.

5. Das S. (2020). Natural therapeutics for urinary tract infections-a review. Future Journal of Pharmaceutical Sciences. 2020; 6(1): 1-13.

6. Adekunle AS, Adekunle OC. Preliminary assessment of antimicrobial properties of aqueous extract of plants against infectious diseases. Biology and Medicine. 2009; 1(3): 20-24.

7. Achan J, Talisuna AO, Erhart A, Yeka A, Tibenderana JK, Baliraine FN, Rosenthal PJ, D'Alessandro U. Quinine, an old anti-malarial drug in a modern world: role in the treatment of malaria. Malaria Journal, 2011; 10(1):144.

8. Liu CX. Discovery and development of artemisinin and related compounds. Chinese Herbal Medicines. 2017; 9(2): 101-114.

9. Grover JK, Yadav S, Vats V. (2002). Medicinal plants of India with anti-diabetic potential. Journal of ethnopharmacology. 2002; 81(1): 81-100.

10. Janovska D, Kubikova K, Kokoska L. Screening for antimicrobial activity of some medicinal plant species of traditional Chinese medicine. Czech. J. Food Sci. 2003; 21: 107-111.

11. Oladele AT, Alade GO, Omobuwajo OR. Me-dicinal plants conservation and cultivation by traditional medicine practitioners (TMPs) in Aiyedaade Local Government Area of Osun State. Agriculture and Biology Journal of North America. 2011; 2(3): 476-487.

12. Sodeinde OA, Salawu KM, Ogbole OO, Ajaiyeoba EO. Phytochemical, antioxidant, brine shrimp lethality and antiproliferative analyses of Solanum dasyphyllum schum. \& thonn. leaf and fruit extracts [Solanaceae]. Savannah Veterinary Journal. 2019; 2(2): 13-17.

13. Indhumathi T, Mohandass S. Efficacy of ethanolic extract of Solanum incanum fruit extract for its antimicrobial activity. Int J Curr Microbiol Appl Sci. 2014; 3(6): 939-949.

14. Sundar S, Pillai JKY. Phytochemical screening and Gas Chromatograph-Mass Spectrometer profiling in the leaves of Solanum incanum L. Asian J Pharm Clin Res. 2015; 8(3): 179-188.

15. Ekwueme FN, Nwodo OFC, Joshua PE, Nkwocha C, Eluka PE. (2015). Qualitative and quantitative phytochemical screening of the aqueous leaf extract of Senna mimosoides: Its effect in in vivo leukocyte mobilization induced by inflammatory stimulus. Int J Curr Micro Appil Sci. 2015; 4: 1176-1188.

16. Yahaya O, Yabefa JA, Umar IO, Datshen MM, Egbunu ZK, Ameh J. (2012). Combine antimicrobial effect of ginger and honey on some human pathogens. British Journal of Pharmacology and Toxicology. 2012; 3(5): 237-239

17. Akinpelu DA, Kolawole DO (2004). Phytochemical and antimicrobial activity of leaf extract of Piliostigma thonningii (Schum.). Sci. Focus J. 2004; 7:64-70.

18. Akinpelu DA, Odewade JO, Aiyegoro OA, Ashafa AO, Akinpelu OF, Agunbiade MO. (2016). Biocidal effects of stem bark extract of Chrysophyllum albidium G. Don on vancomycin-resistant Staphylococcus aureus. BMC complementary and alternative medicine. 2016;16(1): 105. DOI 10.1186/s12906-016-1080-6.

19. Ebrahimzadeh MA, Nabavi SM, Nabavi SF, Bahramian F, Bekhradnia AR. Antioxidant and free radical scavenging activity of $H$. officinalis L. var. angustifolius, V. odorata, B. hyrcana and C. speciosum. Pak J Pharm Sci. 2010; 23(1): 29-34.

20. Phatak RS, Hendre AS. Total antioxidant capacity (TAC) of fresh leaves of Kalanchoe pinnata. Journal of Pharmacognosy and Phytochemistry. 2014; 2(5): 32 - 35.

21. Manal AH, Eltohami MS, Ghada MA. The phytochemical screening and antimicrobial activity of Solanum incanum L. International Journal of Innovative Pharmaceutical Sciences and Research. 2016; 4(2): 87 - 92.

22. Akanmu AO, Bulama YA, Balogun ST, Musa S. (2019). Antibacterial activities of aqueous and methanol leaf extracts of Solanum incanum linn. (Solanaceae) against multi-drug resistant bacterial isolates. African Journal of Microbiology Research. 2019; 13(4): 70-76.

23. Sbhatu DB, Abraha HB. Preliminary antimicrobial profile of Solanum incanum L.: a common medicinal plant. Evidence-Based Complementary and Alternative Medicine. 2020; 2020: 1-6. Available at: https://doi.org/10.1155/2020/3647065 
24. Amutha S. (2014). Screening of antibacterial activity of Solanum melongena seed extracts on selected human pathogenic bacteria. Int J Pharma Bio Sci. 2014; 5(4): 208-213.

25. Prakash S, Jain AK. Antifungal activity and preliminary phytochemical studies of leaf extract of Solanum nigrum Linn. Int. J. Pharm. Sci. 2011; 3: 352355.

26. Compean KL, Ynalvez RA. Antimicrobial activity of plant secondary metabolites: A review. Research Journal of Medicinal Plants. $2014 ;$ 8(5): 204-213.

27. Silva APS, Nascimento da Silva LC, Martins da Fonseca CS, Araújo JM, Correia MTS, Cavalcanti MS, Lima VLM (2016). Antimicrobial activity and phytochemical analysis of organic extracts from Cleome spinosa Jaqc. Front. Microbiol. 2016; 7: 963. doi: 10.3389/fmicb.2016.00963

28. Agbafor KN, Akubugwo El, Ogbashi ME, Ajah PM, Ukwandu CC. Chemical and antimicrobial properties of leaf extracts of Zapoteca portoricensis. Research Journal of Medicinal Plant. 2011; 5(5):605-12.

29. Lelario F, Scrano L, De Franchi S, Bonomo MG, Salzano G, Milan S, Bufo SA. Identification and antimicrobial activity of most representative secondary metabolites from different plant species. Chemical and Biological Technologies in Agriculture. 2018; 5(1):13.

30. Keepers TR, Gomez M, Celeri C, Nichols WW, Krause KM. Bactericidal activity, absence of serum effect, and time-kill kinetics of ceftazidime-avibactam against $\beta$-lactamase producing Enterobacteriaceae and Pseudomonas aeruginosa. Antimicrobial Agents and Chemotherapy. 2014; 58(9): 5297-5305.

31. Oladosu P, Isu NR, Ibrahim K, Okolo P, Oladepo DK. Time kill-kinetics antibacterial study of Acacia nilotica. Afr. J. Microbiol. Res. 2013; 7(46): 52485252.

32. Wojdylo A, Oszmiański J, Czemerys R. Antioxidant activity and phenolic compounds in 32 selected herbs. Food Chemistry. 2007; 105(3): 940-949.

33. Marchese A, Arciola CR, Barbieri R, Silva AS, Nabavi SF, Tsetegho SAJ, Izadi M, Jafari NJ, Suntar I, Daglia M, Nabavi SM. (2017). Update on monoterpenes as antimicrobial agents: A particular focus on p-cymene. Materials. 2017; 10(8): 947.

34. Seol GH, Kim KY. Eucalyptol and its role in chronic diseases. In Drug Discovery from Mother Nature (p. 389-398). Springer, Cham. 2016. doi: 10.1007/978-3-319-41342-6_18

35. Mikaili P, Mojaverrostami S, Moloudizargari M, Aghajanshakeri S. Pharmacological and therapeutic effects of Mentha Longifolia L. and its main constituent, menthol. Ancient Science of Life. 2013; 33(2): 131.

36. Chavan MJ, Wakte PS. and Shinde DB. (2010). Analgesic and anti-inflammatory activity of Caryophyllene oxide from Annona squamosa L. bark. Phytomedicine. 2010;17(2):149-151.

37. Jasim H, Hussein AO, Hameed IH, Kareem MA. Characterization of alkaloid constitution and evaluation of antimicrobial activity of Solanum nigrum using Gas Chromatography Mass Spectrometry (GC-MS). Journal of Pharmacognosy and Phytotherapy. 2015; 7(4): 56-72.

38. El-Shaboury G, Haroun S, Shaker K, Badr A. Systematics Implications of GC-MS Analysis of Secondary Metabolites in the Ethanol Extract of Solanum Species from South West Saudi Arabia. Egyptian Journal of Botany. 2017; 57(3): 429-444.

\section{Tables}

Table 1: Preliminary qualitative and quantitative phytochemical screening of the crude methanolic extract of $S$. dasyphyllum leaves Phyto-constituents Qualitative data Quantitative data

\begin{tabular}{ccc}
\hline Flavonoids & + & 0.0063 \\
Alkaloids & ++ & 1.284 \\
Saponins & + & 0.395 \\
Cyanogenic glycosides & + & 0.016 \\
Tannins & + & 0.037 \\
Reducing-sugars & + & 0.863 \\
\hline
\end{tabular}

Table 2: Activities of the crude methanolic extract and fractions of $S$. dasyphyllum against clinical bacterial isolates 


\begin{tabular}{cccccc}
\hline Test sample/control & Conc $(\mathrm{mg} / \mathrm{mL})$ & E. Coli & Ps. aeruginosa & B. Subtilis & S. aureus \\
\cline { 3 - 6 } & & \multicolumn{3}{c}{ Zones of growth inhibition $(\mathrm{mm})$} \\
\hline MESd1 & 2 & $18 \pm 1.1$ & $18 \pm 0.23$ & $20 \pm 1.1$ & $20 \pm 1.4$ \\
MESd2 & 1 & $16 \pm 2.1$ & $14 \pm 2.4$ & $18 \pm 1.4$ & $16 \pm 2.2$ \\
MESd3 & 0.5 & - & $12 \pm 0.1$ & $12 \pm 0.2$ & $10 \pm 0.3$ \\
\hline Gentamicin & $10(\mu \mathrm{g} / \mathrm{ml})$ & $20 \pm 0.2$ & $22 \pm 2.3$ & $20 \pm 0.3$ & $24 \pm 2.3$ \\
\hline Methanol & $(80 \% \mathrm{v} / \mathrm{v})$ & - & - & - & - \\
\hline SdHXF1 & 2 & $15 \pm 0.2$ & $14 \pm 1.1$ & $16 \pm 1.2$ & $16 \pm 0.2$ \\
\hline SdHXF2 & 1 & $12 \pm 1.2$ & $12 \pm 0.4$ & $14 \pm 0.2$ & $14 \pm 1.2$ \\
\hline SdHXF3 & 0.5 & - & $10 \pm 2.1$ & $14 \pm 0.3$ & $12 \pm 0.5$ \\
\hline Gentamicin & $10(\mu \mathrm{g} / \mathrm{ml})$ & $16 \pm 0.1$ & $16 \pm 1.1$ & $20 \pm 3.0$ & $18 \pm 2.3$ \\
\hline Methanol & $(80 \% \mathrm{v} / \mathrm{v})$ & - & - & - & - \\
SdDMF1 & 2 & $12.1 \pm 0.2$ & $18 \pm 0.7$ & $20 \pm 0.5$ & $21 \pm 0.3$ \\
\hline SdDMF2 & 1 & $9 \pm 0.1$ & $12 \pm 0.1$ & $20 \pm 1.6$ & $16 \pm 1.8$ \\
\hline SdDMF3 & 0.5 & $11 \pm 0.1$ & $9 \pm 1.6$ & $15 \pm 0.4$ & $11 \pm 1.8$ \\
\hline Gentamicin & $10 \mu \mathrm{g} / \mathrm{mL}$ & $21 \pm 0.4$ & $22.1 \pm 0.8$ & $23 \pm 1.1$ & $24 \pm 0.1$ \\
\hline Methanol & $(80 \% \mathrm{v} / \mathrm{v})$ & - & - & - & - \\
\hline SdEAF1 & 2 & $14 \pm 0.1$ & $20 \pm 1.3$ & $22 \pm 0.3$ & $22 \pm 0.51$ \\
\hline SdEAF2 & 1 & $12 \pm 0.6$ & $12 \pm 0.3$ & $20 \pm 1.1$ & $16 \pm 1.1$ \\
\hline SdEAF3 & 0.5 & $12 \pm 0.4$ & $10 \pm 2.3$ & $16 \pm 1.2$ & $12 \pm 1.1$ \\
\hline Gentamicin & $10(\mu \mathrm{g} / \mathrm{ml})$ & $22 \pm 2.1$ & $22 \pm 0.5$ & $24 \pm 0.2$ & $25 \pm 0.7$ \\
\hline Mathanol & $(80 \% \mathrm{v} / \mathrm{v})$ & - & - & - & - \\
\hline SdAQF1 & 2 & $18 \pm 0.3$ & $18 \pm 2.5$ & $15 \pm 2.2$ & $14 \pm 0.1$ \\
\hline SdAQF2 & 1 & $16 \pm 2,2$ & $14 \pm 1.2$ & $14 \pm 1.4$ & $12 \pm 1.4$ \\
\hline SdAQF3 & 0.5 & $14 \pm 1.3$ & $12 \pm 0.2$ & $12 \pm 0.2$ & $10 \pm 0.3$ \\
\hline Gentamicin & $10(\mu \mathrm{g} / \mathrm{ml})$ & $22 \pm 2.2$ & $18 \pm 0.3$ & $20 \pm 1.2$ & $18 \pm 1.3$ \\
\hline Methanol & $(80 \% \mathrm{v} / \mathrm{v})$ & - & - & - & - \\
\hline
\end{tabular}

Legend: MESd- Methanol Extract of S. dasyphyllum, SdHXF- n-hexane fraction, SdDMF-dichloromethane fraction, SdEAF- ethylacetate fraction and SdAQF- aqueous fraction, - =No zone of inhibition.

Table 3: Activities of the crude methanolic extract and fractions of $S$. dasyphyllum against clinical fungal isolates Test sample/control Conc (mg/mL) Candida albicans Penicillum sp. Rhizopus sp. Aspergillus niger

\begin{tabular}{cccccc} 
& & & Zones of growth inhibition $(\mathrm{mm})$ & \\
\cline { 3 - 5 } MESd1 & 2 & $12 \pm 1.2$ & $18 \pm 0.2$ & $16 \pm 1.3$ & $18 \pm 1.2$ \\
MESd2 & 1 & - & $16 \pm 1.4$ & $14 \pm 2.2$ & $16 \pm 3.2$ \\
MESd3 & 0.5 & - & $14 \pm 2.2$ & $13 \pm 3.1$ & $14 \pm 0.2$ \\
\hline Ketoconazole & $10(\mu \mathrm{g} / \mathrm{mL})$ & $16 \pm 0.7$ & $20 \pm 0.4$ & $22 \pm 5.2$ & $20 \pm .44$ \\
Methanol & $(80 \% \mathrm{v} / \mathrm{v})$ & - & - & - & - \\
\hline SdHXF1 & 2 & $16 \pm 0.1$ & $20 \pm 0.5$ & $16 \pm 1.5$ & $14 \pm 2.1$ \\
\hline SdHXF2 & 1 & $14 \pm 1.1$ & $16 \pm 0.1$ & $14 \pm 2.2$ & $12 \pm 1.0 .1$ \\
\hline SdHX3 & 0.5 & $12 \pm 0.1$ & $14 \pm 1.4$ & $14 \pm 0.3$ & $10 \pm 4.3$ \\
\hline Ketoconazole & $10(\mu \mathrm{g} / \mathrm{mL})$ & $18 \pm 1.4$ & $22 \pm 0.1$ & $20 \pm 0.4$ & $16 \pm 2.2$ \\
\hline Methanol & $(80 \% \mathrm{v} / \mathrm{v})$ & - & - & - & - \\
\hline SdDMF1 & 2 & $14.1 \pm 0.1$ & $19 \pm 0.1$ & $18 \pm 3.0$ & $21 \pm 0.6$ \\
\hline SdDMF2 & 1 & $114 \pm 0.3$ & $14 \pm 1.8$ & $15 \pm 2.2$ & $19 \pm 0.8$ \\
\hline SdDMF3 & 0.5 & $9 \pm 1.4$ & $13 \pm 1.2$ & $14 \pm 0.1$ & $13 \pm 1.8$ \\
\hline Ketoconazole & $10(\mu \mathrm{g} / \mathrm{mL})$ & $16 \pm 1.3$ & $23 \pm 0.3$ & $18 \pm 1.1$ & $22 \pm 1.4$ \\
\hline Methanol & $(80 \% \mathrm{v} / \mathrm{v})$ & - & - & - & - \\
\hline SdEAF1 & 2 & $14 \pm 0.1$ & $20 \pm 0.2$ & $18 \pm 3.2$ & $22 \pm 3.5$ \\
\hline SdEAF2 & 1 & $12 \pm 0.3$ & $14 \pm 2.3$ & $16 \pm 2.3$ & $20 \pm 0.4$ \\
\hline SdEAF3 & 0.5 & $10 \pm 2.3$ & $12 \pm 1.4$ & $14 \pm 1.1$ & $13 \pm 2.2$ \\
\hline Ketoconazole & $10(\mu \mathrm{g} / \mathrm{mL})$ & $16 \pm 2.2$ & $24 \pm 0.4$ & $20 \pm 0.2$ & $24 \pm 3.4$ \\
\hline Methanol & $(80 \% \mathrm{v} / \mathrm{v})$ & - & - & - & -
\end{tabular}

Legend: MESd- Methanol Extract of S. dasyphyllum, SdHXF- n-hexane fraction, SdDM-dichloromethane fraction, SdEAF- ethylacetate fraction and SdAQF- aqueous fraction, - =No zone of inhibition

Table 4: Determination of minimum inhibitory concentrations (MICs), minimum bactericidal/fungicidal concentrations (MB/FC) and the $\mathrm{MB} / \mathrm{FC} / \mathrm{MIC}$ ratio of the crude methanolic extract and fractions against clinical isolates 


\begin{tabular}{|c|c|c|c|c|c|c|c|c|c|c|c|c|c|c|c|}
\hline \multirow{3}{*}{$\begin{array}{c}\text { Test } \\
\text { microbes }\end{array}$} & \multicolumn{15}{|c|}{ Extract/Fractions (Concentrations (mg/mL) } \\
\hline & \multicolumn{3}{|c|}{ MESd } & \multicolumn{3}{|c|}{ SdHXF } & \multicolumn{3}{|c|}{ SdDMF } & \multicolumn{3}{|c|}{ SdEAF } & \multicolumn{3}{|c|}{ SdAQF } \\
\hline & MIC & $\begin{array}{l}\text { MBC } \\
\text { or } \\
\text { MFC }\end{array}$ & $\begin{array}{c}\text { MBC or } \\
\text { MFC/MIC } \\
\text { Ratio } \\
\end{array}$ & MIC & $\begin{array}{l}\text { MBC } \\
\text { or } \\
\text { MFC }\end{array}$ & $\begin{array}{c}\text { MBC or } \\
\text { MFC/MIC } \\
\text { Ratio } \\
\end{array}$ & MIC & $\begin{array}{l}\text { MBC } \\
\text { or } \\
\text { MFC }\end{array}$ & $\begin{array}{c}\text { MBC or } \\
\text { MFC/MIC } \\
\text { Ratio }\end{array}$ & MIC & $\begin{array}{l}\text { MBC } \\
\text { or } \\
\text { MFC }\end{array}$ & $\begin{array}{c}\text { MBC or } \\
\text { MFC/MIC } \\
\text { Ratio }\end{array}$ & MIC & $\begin{array}{l}\text { MBC } \\
\text { or } \\
\text { MFC }\end{array}$ & $\begin{array}{c}\text { MBC or } \\
\text { MFC/MIC } \\
\text { Ratio } \\
\end{array}$ \\
\hline S. aureus & 2 & $>4$ & $>2^{*}$ & 4 & 4 & 1 & 0.50 & 4 & $8^{*}$ & 4 & $>4$ & $>1^{*}$ & 4 & 4 & 1 \\
\hline B. subtilis & 0.25 & 1 & 4 & 1 & 4 & 4 & 0.50 & 2 & 4 & 4 & 4 & 1 & 1 & 2 & 2 \\
\hline E. coli & 4 & $>4$ & $>1 *$ & 4 & 4 & 1 & 4 & 4 & 1 & 4 & $>4$ & $>1 *$ & 2 & 4 & 2 \\
\hline $\begin{array}{c}P . \\
\text { earuginosa }\end{array}$ & 2 & 2 & 1 & 1 & 4 & 4 & 0.50 & 2 & 4 & 1 & 2 & 2 & 0.50 & 2 & 4 \\
\hline $\begin{array}{c}\text { Aspergillus } \\
\text { niger }\end{array}$ & 4 & $>4$ & $>1 *$ & 2 & $>4$ & $>2^{*}$ & 0.25 & 0.5 & 2 & 0.50 & 4 & 8* & 4 & $>4$ & $>1 *$ \\
\hline $\begin{array}{l}\text { Rhizopus } \\
\text { specie }\end{array}$ & 4 & 4 & 1 & 2 & $>4$ & $>2^{*}$ & 0.25 & 1 & 4 & 0.25 & 2 & 8* & 0.50 & 2 & 4 \\
\hline $\begin{array}{l}\text { Candida. } \\
\text { albicans }\end{array}$ & 4 & 4 & 1 & $>4$ & $>4$ & 1 & 1 & 2 & 2 & 0.5 & 4 & 8* & 4 & $>4$ & $>1 *$ \\
\hline $\begin{array}{l}\text { Penicillium } \\
\text { specie }\end{array}$ & 4 & $>4$ & $>1 *$ & 2 & $>4$ & $>2 *$ & 0.25 & 1 & 4 & 0.5 & $>4$ & $>8^{*}$ & 1 & 2 & 2 \\
\hline
\end{tabular}

.egend: MESd- Methanol Extract of $S$. dasyphyllum, SdHXF- n-hexane fraction, SdDMF, dichloromethane fraction, SdEAF- ethylacetate fraction, SdAQF- aqueous fraction, MIC-minimum inhibitory concentration, MB/FC-minimum bactericidal/fungicidal concentration, *-bacteriostatic action.

Table 5: Determination of antioxidant and free radical scavenging property of the methanolic extract of $S$ dasyphyllum leaves in comparison with standards

\begin{tabular}{|c|c|c|c|}
\hline Test & Concentrations $(\mu \mathrm{g} / \mathrm{ml})$ & $\begin{array}{l}\text { Crude Extract } \\
\text { Absorbance }\end{array}$ & Standard Absorbance \\
\hline \multirow{6}{*}{ TPC } & & MESd at $765 \mathrm{~nm}$ & GAL at $765 \mathrm{~nm}$ \\
\hline & 200 & $0.104 \pm 0.00$ & $1.525 \pm 0.0006$ \\
\hline & 400 & $0.131 \pm 0.00$ & $1.620 \pm 0.0006$ \\
\hline & 600 & $0.165 \pm 0.00$ & $1.837 \pm 0.0005$ \\
\hline & 800 & $0.223 \pm 0.00$ & $1.917 \pm 0.0006$ \\
\hline & 1000 & $0.253 \pm 0.00$ & $2.043 \pm 0.0005$ \\
\hline \multirow[t]{6}{*}{ FRAP } & & MESd at $700 \mathrm{~nm}$ & ASA at $700 \mathrm{~nm}$ \\
\hline & 200 & $0.027 \pm 0.00$ & $0.582 \pm 0.001$ \\
\hline & 400 & $0.153 \pm 0.0006$ & $0.947 \pm 0.001$ \\
\hline & 600 & $0.288 \pm 0.001$ & $1.451 \pm 0.0006$ \\
\hline & 800 & $0.293 \pm 0.0006$ & $1.5513 \pm 0.0015$ \\
\hline & 1000 & $0.298 \pm 0.001$ & $1.604 \pm 0.001$ \\
\hline \multirow[t]{6}{*}{ TAC } & & MESd at $695 \mathrm{~nm}$ & ASA at $695 \mathrm{~nm}$ \\
\hline & 200 & $0.009 \pm 0.0006$ & $1.750 \pm 0.00$ \\
\hline & 400 & $0.016 \pm 0.0012$ & $1.895 \pm 0.00$ \\
\hline & 600 & $0.037 \pm 0.0006$ & $1.901 \pm 0.0006$ \\
\hline & 800 & $0.047 \pm 0.0006$ & $1.910 \pm 0.00$ \\
\hline & 1000 & $0.049 \pm 0.0012$ & $1.932 \pm 0.0006$ \\
\hline \multirow[t]{6}{*}{ DPPH } & & MESd at $517 \mathrm{~nm}$ & ASA at $517 \mathrm{~nm}$ \\
\hline & 200 & $0.400 \pm 0.0006$ & $0.059 \pm 0.0006$ \\
\hline & 400 & $0.230 \pm 0.002$ & $0.059 \pm 0.001$ \\
\hline & 600 & $0.189 \pm 0.0006$ & $0.058 \pm 0.0006$ \\
\hline & 800 & $0.187 \pm 0006$ & $0.057 \pm 0.00$ \\
\hline & 1000 & $0.185 \pm 0.001$ & $0.042 \pm 0.002$ \\
\hline
\end{tabular}

Legend: MESd - Methanol Extract of S. dasyphyllum, ASA - Ascorbic acid, GAL - Garlic acid, TAC - Total Antioxidant Capacity, TPC -

Total Phenol Content, FRAP - Ferric ion reducing antioxidant power, DPPH - 1,1-diphenyl-2-picryl hydrazyl assay

Table 6: GCMS analysis showing the chemical constituents of the crude methanolic extract of $S$. dasyphyllum leaves 


\begin{tabular}{|c|c|c|c|c|}
\hline $\begin{array}{l}\text { Serial } \\
\text { No. }\end{array}$ & Constituents & $\begin{array}{c}\text { Retention time } \\
\text { (min) }\end{array}$ & $\begin{array}{l}\text { Peak } \\
\text { area }\end{array}$ & $\begin{array}{l}\text { Total } \\
(\%)\end{array}$ \\
\hline 1 & Benzene, 1-methyl-3-(1-methylethyl & 4.687 & 3369974 & 1.202 \\
\hline 2 & Eucalyptol & 4.787 & 11349796 & 4.047 \\
\hline 3 & Levomenthol & 6.622 & 7400539 & 2.639 \\
\hline 4 & 2(4H)-Benzofuranone, 5,6,7,7a-tetr ahydro-4,4,7a-trimethyl-, (R)- & 10.518 & 1967511 & 0.702 \\
\hline 5 & Diethyl Phthalate & 11.218 & 1358949 & 0.485 \\
\hline 6 & Paradrine & 12.757 & 4212600 & 1.502 \\
\hline 7 & 2-Pentadecanone, 6,10,14-trimethyl & 13.920 & 12897177 & 4.599 \\
\hline 8 & Neophytadiene & 13.982 & 4793467 & 1.709 \\
\hline 9 & Cyclotetradecane & 14.221 & 2438364 & 0.870 \\
\hline 10 & Methyl 11-methyl-dodecanoate & 14.613 & 4181829 & 1.491 \\
\hline 11 & n-Hexadecanoic acid & 14.960 & 41749276 & 14.888 \\
\hline 12 & 1-Docosene & 15.946 & 1206020 & 0.430 \\
\hline 13 & Phytol & 16.208 & 11567479 & 4.125 \\
\hline 14 & 9,12-Octadecadienoic acid (Z,Z)- & 16.320 & 10934469 & 3.899 \\
\hline 15 & 9-Octadecenoic acid & 16.382 & 21205470 & 7.562 \\
\hline 16 & 17-Pentatriacontene & 17.272 & 7189211 & 2.564 \\
\hline 17 & delta.-Dodecalactone & 17.905 & 2699731 & 0.963 \\
\hline 18 & 3,6-Octadien-1-ol, 3,7-dimethyl-, (Z)- & 18.366 & 7910832 & 2.821 \\
\hline 19 & Thunbergol & 18.395 & 2604394 & 0.929 \\
\hline 20 & 3-buten-2-one, 4-(5,5-dimethyl-1-oxaspiro[2.5] oct-4-yl) & 18.442 & 3936300 & 1.404 \\
\hline 21 & trans-Sesquisabinene hydrate & 18.590 & 36539798 & 13.030 \\
\hline 22 & Caryophyllene oxide & 18.642 & 4095689 & 1.461 \\
\hline 23 & cis-11-Hexadecenal & 18.804 & 13638063 & 4.863 \\
\hline 24 & 9,17-Octadecadienal, (Z)- & 19.689 & 18339012 & 6.540 \\
\hline 25 & Zinc, dicyclopentyl- & 19.922 & 5794112 & 2.066 \\
\hline 26 & $\begin{array}{l}\text { 1,2-Pentanediol, 5-(6-bromodecahyd ro-2-hydroxy-2,5,5a,8a-tetramethyl-1- } \\
\text { naphthalenyl)-3-methylene- }\end{array}$ & 20.057 & 17905812 & 6.385 \\
\hline 27 & $\mathrm{Z}, \mathrm{E}-2,13$-Octadecadien-1-ol & 20.238 & 7790870 & 2.778 \\
\hline 28 & Decane, 1,10-dibromo- & 20.457 & 5150169 & 1.837 \\
\hline 29 & 1H-Indene, 5-butyl-6-hexyloctahydro- & 20.554 & 6198656 & 2.210 \\
\hline
\end{tabular}

\section{Figures}

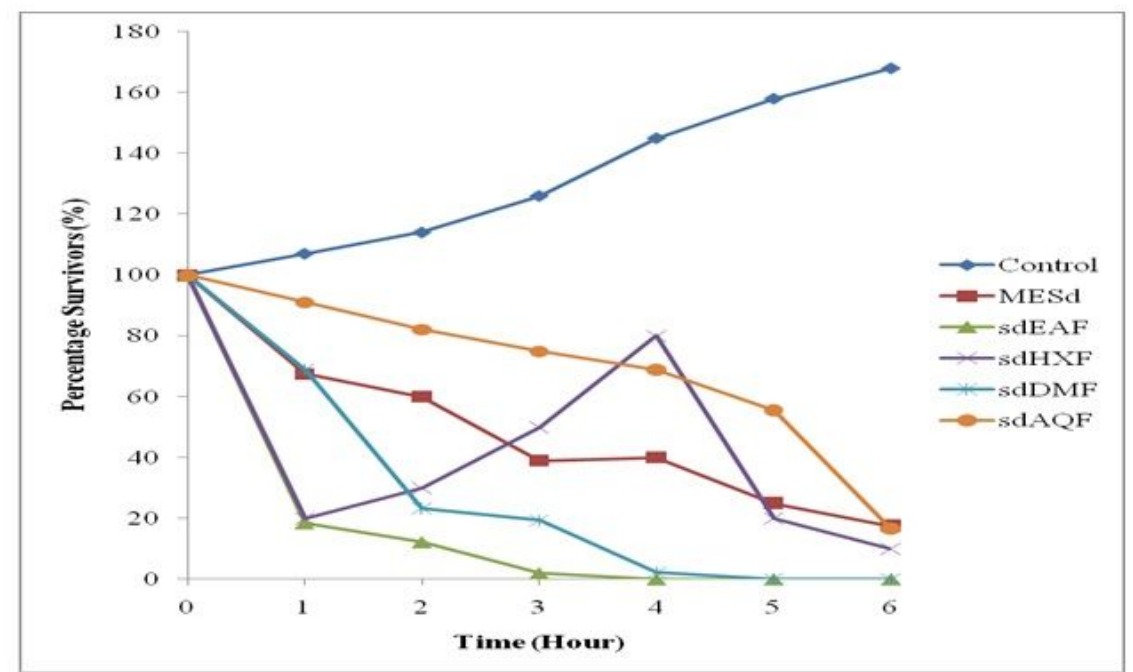

Legend: MESd- Methanolic extract of S. dasyphyllum, SdHXF- n-hexane fraction, SdDMF, dichloromethane fraction, SdEAF- ethylacetate fraction and SdAQF- aqueous fraction

\section{Figure 1}

Time-kill kinetics of the extract and fractions of S. dasyphyllum leaves against clinical isolate of Staphylococcus aureus 


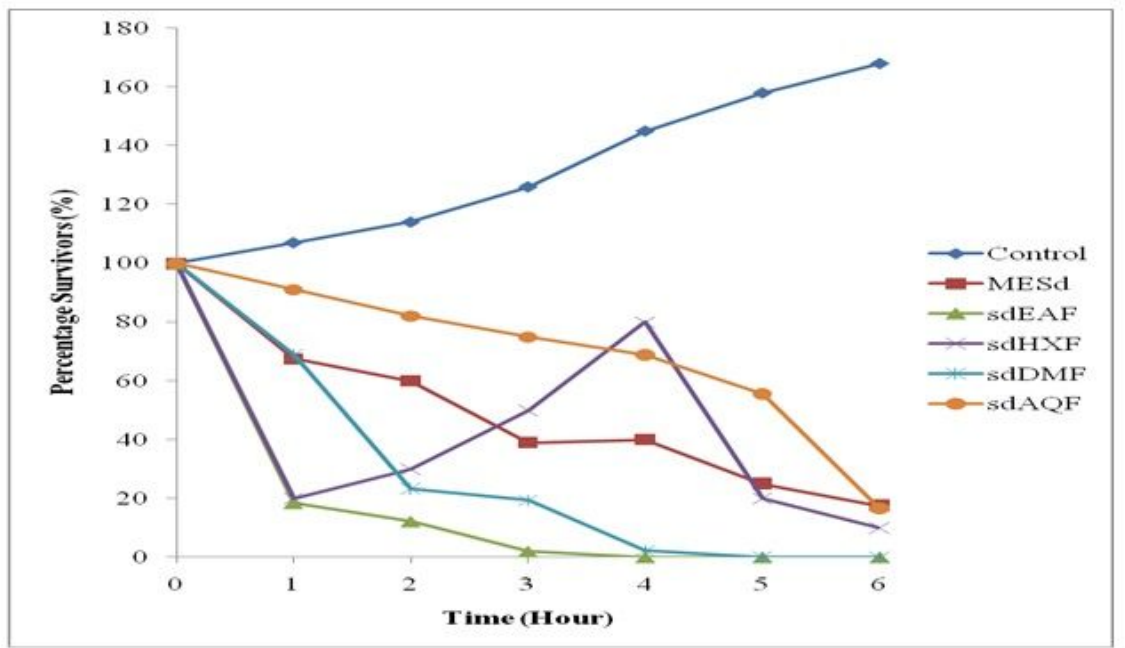

Legend: MESd- Methanol Extract of S. dasyphyllum, SdHXF- n-hexane fraction, SdDMF, dichloromethane fraction, SdEAF- ethylacetate fraction and SdAQF- aqueous fraction

\section{Figure 2}

Time-kill kinetics of the extract and fractions of S. dasyphyllum leaves against clinical isolate of Escherichia coli

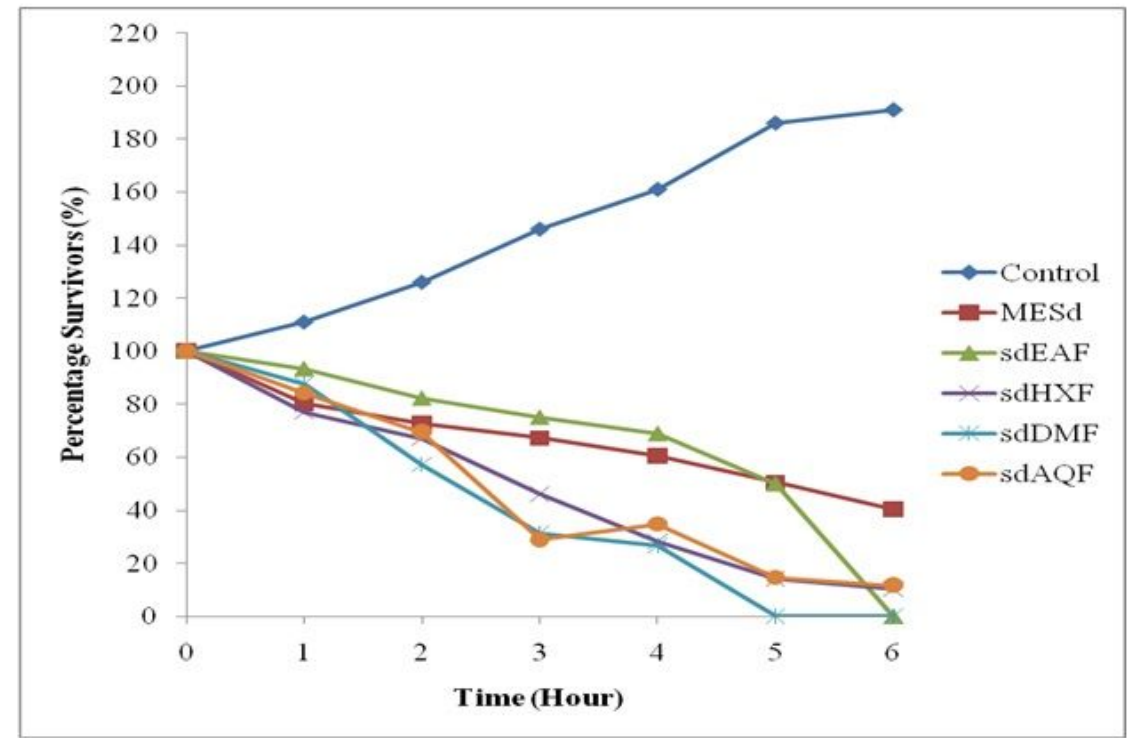

Legend: MESd- Methanol Extract of S. dasyphyllum, SdHXF- n-hexane fraction, SdDMF,

dichloromethane fraction, SdEAF- ethylacetate fraction and SdAQF- aqueous fraction

\section{Figure 3}

Time-kill kinetics of the extract and fractions of S. dasyphyllum leaves against clinical isolate of Candida albicans 


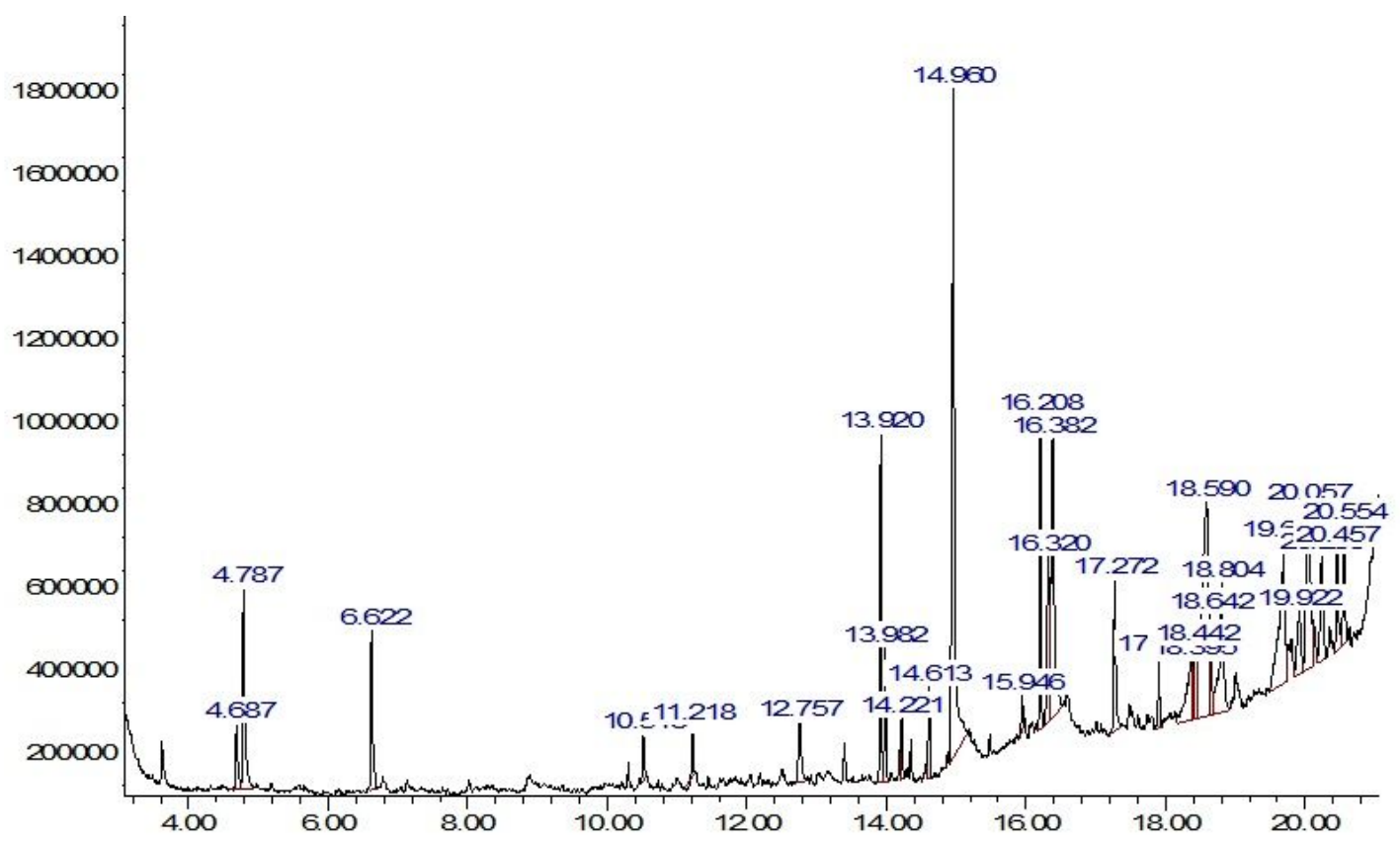

Figure 4

Total ion current chromatogram of the crude methanolic extract of S. dasyphyllum leaves 